\title{
On Fennoscandian polypores 7. The genus Pycnoporellus
}

\author{
TUOMO NIEMELÄ
}

\begin{abstract}
NIEMELÄ, T. 1980: On Fennoscandian polypores 7. The genus Pycnoporellus. Karstenia 20: $1-15$.

Descriptions are given of the two species of Pycnoporellus occurring in Fennoscandia, P. alboluteus (Ell. \& Ev.) Kotl. \& Pouz. and P. fulgens (Fr.) Donk. Their distributions in North Europe are mapped, and their world distributions reviewed. Their ecology, phenology, host relationships, and cultural and microscopical characters are discussed. Great variability exists in the microscopical characters of both species. $P$. alboluteus is very rare in North Europe, where it has been recorded from only two localities in northern Finland, on Picea abies and once on Alnus incana. P. fulgens is rare and south-eastern in distribution, being known from four Swedish localities and several localities in southern Finland and the adjacent U.S.S.R., mostly on Picea abies, but also on Pinus sylvestris, Populus tremula and Betula.

Study of the types indicates that the names Irpex woronowii Bres. and Lenzites sepiaria var. dentifera Peck are synonymous with $P$. alboluteus, and that Ochroporus lithuanicus Błoński (type selected), Polyporus aurantiacus Peck and P. fibrillosus Karst. are synonymous with $P$. fulgens. The taxonomic position of the genus Pycnoporellus is discussed.
\end{abstract}

Tuomo Niemelä, Department of Botany, University of Helsinki, Unioninkatu 44, SF - 00170 Helsinki 17, Finland.

\section{Introduction}

The genus Pycnoporellus Murrill comprises two species in Europe, both rather rare inhabitants of old spruce-dominated forests. The existence of $P$. alboluteus (Ell. \& Ev.) Kotl. \& Pouz. in Europe was established relatively lately (Pilát 1936-1942), and it was reported from northern Europe only ten years ago (Hintikka 1970). P. fulgens (Fr.) Donk has been known from Europe since the time of Elias Fries, but its distribution in North Europe has not been surveyed before.

The microscopical characters show that the two species form a good genus. However, the situation of Pycnoporellus in the classification of the polypores is not yet clearly fixed, even at the family level. Some noteworthy studies have been made of the genus and its taxonomy (especially by Kotlaba \& Pouzar 1963). In this paper an attempt has been made to compile the information contained by these studies and supplement it with the results of my own investigations and field observations.

\section{Materials and methods}

The descriptions are based on the specimens deposited in the herbaria GB, H, HFR, OULU, S, TUR, UPS, and the collections of Heikki Kotiranta (H.K.) and Tuomo Niemelä (T.N.). Types were obtained from NY and NYS, as well. The procedures followed in measuring the structural details, and collecting the other data were the same as in my previous papers in the series on the Fennoscandian polypores. However, the measurements and drawings were made from microscopical sections mounted in $5 \% \mathrm{KOH}$. The illustrations are my own, and the photographs represent fresh specimens.

The cultural characters were studied on malt agar. The strains are kept in the collection of the author, and deposited at $\mathrm{H}$.

\section{Pycnoporellus}

The originally monotypic genus Pycnoporellus was described by Murrill (1905) with the generic type $P$. fibrillosus (P. fulgens). The genus Aurantiporellus Murr. was described at the same time, with $A$. alboluteus as its type and only species, but was later 
made a synonym of Pycnoporellus by Kotlaba and Pouzar (1963).

The species of the genus are characterized by a monomitic hyphal system, clampless septa in the hyphae, narrowly ellipsoid spores with no reactions in Melzer's reagent or Cotton Blue, and prominent tubular cystidioles in the hymenium. The hyphae are thin-walled in young fruit bodies, but become sclerified towards the end of growth, and stain red in $\mathrm{KOH}$, especially in the old stage. The fruit bodies are annual or survive to the beginning of the next growing season.

The situation of the genus has been much discussed. Many authors stress the similarities with the genus Phaeolus: the monomitic hyphal system, the lack of clamp connections, and the presence of long, thin-walled cystidioles. Pycnoporellus and Phaeolus do seem to be allied genera, but are clearly separated by their enzymes (David 1969) and pigments (Parmasto \& Parmasto 1979). Phaeolus, and also Pycnoporellus (Pegler 1973) have sometimes been considered to belong to the family Hymenochaetaceae, an opinion which I do not share. The microscopical characters (especially the hymenial differences) and different enzyme systems, pigments and colour reactions separate these genera distinctly from Inonotus, Onnia, Phellinus and the other representatives of the Hymenochaetaceae.

A genus which may be quite close to Pycnoporellus is Laetiporus. The latter is regarded as dimitic (amphimitic), having clampless generative hyphae and sclerified binding hyphae. The structure of the context or subiculum in Pycnoporellus, though monomitic, shows similar differentiation into elongated, rarely branched hyphae and thinner, ramified branches, which resemble the binding hyphae of Laetiporus.

The separation of generative, skeletal and binding hyphae in the microscopical structure of Aphyllophorales was an important innovation and is a useful tool for taxonomy. But in my opinion this division has sometimes been followed too rigorously. Examples of cases which do not fit into the triple division are Dichomitus with 'arboriform skeletal hyphae' (Reid 1965) and Phellinus with distinctly septate skeletoid hyphae. The subsolid, ramified side branches in the hyphae of e.g. Tyromyces lowei are also difficult to classify according to this system: Lowe (1975) treats the species as dimitic with binding hyphae, while many others (e.g. Ryvarden 1978) regard it as monomitic.

Therefore the amphimitic structure of Laetiporus vs. the monomiticity of Pycnoporellus may not be a very fundamental difference, though showing a different degree of hyphal specialization. The genus Pycnoporellus is a good example of the difficulties encountered in the gross taxonomy of the polypores. In the definition of the families and other groups, consideration should be given to all the characters, including the enzyme systems and nuclear characters, and undue reliance should not be placed on some single features, such the hyphal systems, or the cyanophily of the spores.

\section{Pycnoporellus alboluteus}

Fomes alboluteus Ellis \& Everhart, Proc. Acad. Nat. Sci. Philadelphia 1895: 413. 1895. Holotype: Fomes alboluteus E. \& E., (U.S.A.,) Mountains of Colorado, on charred trunks of Abies subalpina ( $=A$. lasiocarpa), $10000 \mathrm{ft}$ alt., July 1894 C.S. Crandall 50 (NY). - Aurantiporellus alboluteus (Ell. \& Everh.) Murrill, Bull. Torrey Bot. Club 32: 486. 1905. - Pvcnoporellus alboluteus (Ell. \& Everh.) Kotlaba \& Pouzar, Česká Mykologie 17: 174. 1963.

Lenzites sepiaria (Fr.) Fr. var. dentifera Peck, N.Y. State Mus. Ann. Rep. 40: 75. 1887. Holotype: Lenzites sepiaria Fr. var. dentifera Fr., (U.S.A., New York,) Adirondack Mts., on spruce, C.H. Peck (NYS).

Irpex woronowii Bresadola, Ann. Mycol. 18: 42.1920. Holotype: Irpex(?) woronowii Bres., (U.S.S.R., Georgian S.S.R.,) Abkhazia, Jugum Bekil-Bgallara, ad truncum fagineum, 1.VIII.1912 G. Woronow 260 (S).

Further combinations listed by Donk (1974).

Fruit body annual or persisting to the next spring. Consistency in young fruit bodies elastic in fresh material and brittle in dry, in mature stage soft corky and not changing much when drying. Taste mild.

Resupinate, seldom indistinctly effused-reflexed with false pilei. Effused parts very variable in size, mostly $2-10 \times 5-40 \mathrm{~cm}$, on big tree trunks even $0.5-2$ metres long; 5-13 mm thick (Fig. 1). Margin of effused fruit bodies entire or lacunose, without well-delimited sterile zone. False pilei irregular, pendent with laterally open tubes (Fig. 3), or formed by agglomerations of radially oriented, malformed tubes (Figs. 2, 4), nodular, ruff-like, ca. $1-2 \times 2.5$ $\mathrm{cm}$, projecting $1-2 \mathrm{~cm}$ from substrate, without distinct context or differentiated upper surface.

Pores on the upper surface and margin of false pilei coarse, irregular and becoming lacunose and finally foliose. Pores on the effused parts coarse, angular, irregular, 3-7 (-9) per $\mathrm{cm}$, later fusing together and becoming very large and sinuose; mouths dentate from the beginning, finally lacerate. Tubes finally $0.5-2 \mathrm{~cm}$ long. Subiculum very thin, $0.5-1(-3)$ $\mathrm{mm}$ in thickness.

Overall colour at first pale yellowish or orangeyellowish, in mature stage from orange and salmon to apricot, weathered fruit bodies pale greyish apricot and finally darkening to light brick red. Colours 


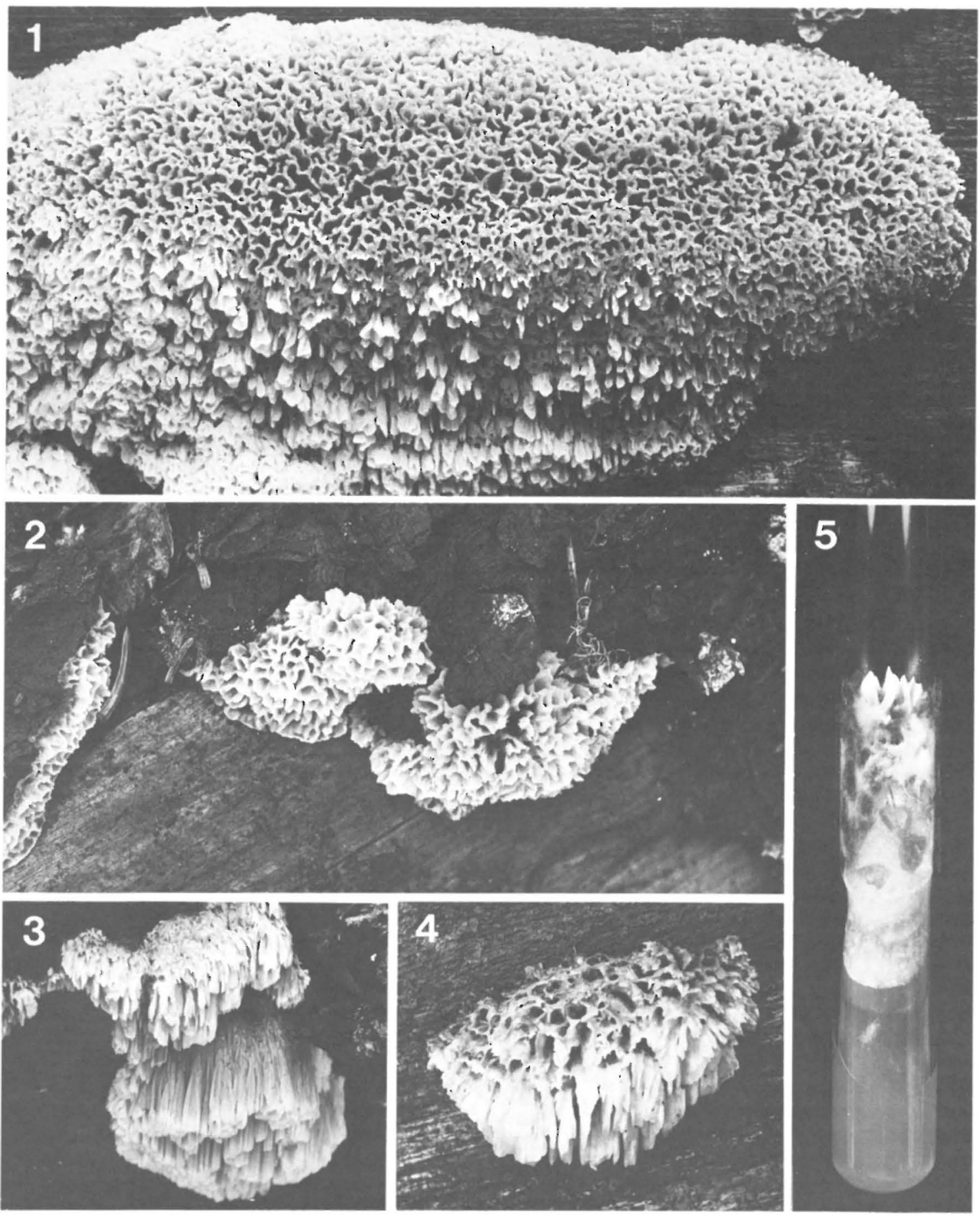

Figs. 1-5. Pycnoporellus alboluteus. - 1: Part of a mature fruit body (Poland, Białowieża, Picea abies, 1969 Niemelä 344 , $\times 1$ ). -2 : Young, ruff-like nodules on the upper side of partly decorticated trunk (Finland, Pisavaara, $P$. abies, 1979 Niemelä 1551 \& Kotiranta, $\times 0.8)$. -3 : Pendent false pilei (1979 Niemelä 1551 \& Kotiranta, $\times 0.8)$. -4 : Fruit body on Alnus incana (Pisavaara, 1979 Niemelä $1543 \&$ Kotiranta, $\times 1.7) .-5$ : Fructification emerging in a stored culture (strain Niemelä 1551 \& Kotiranta, malt agar, kept at $+5^{\circ} \mathrm{C}$, for half a year). 

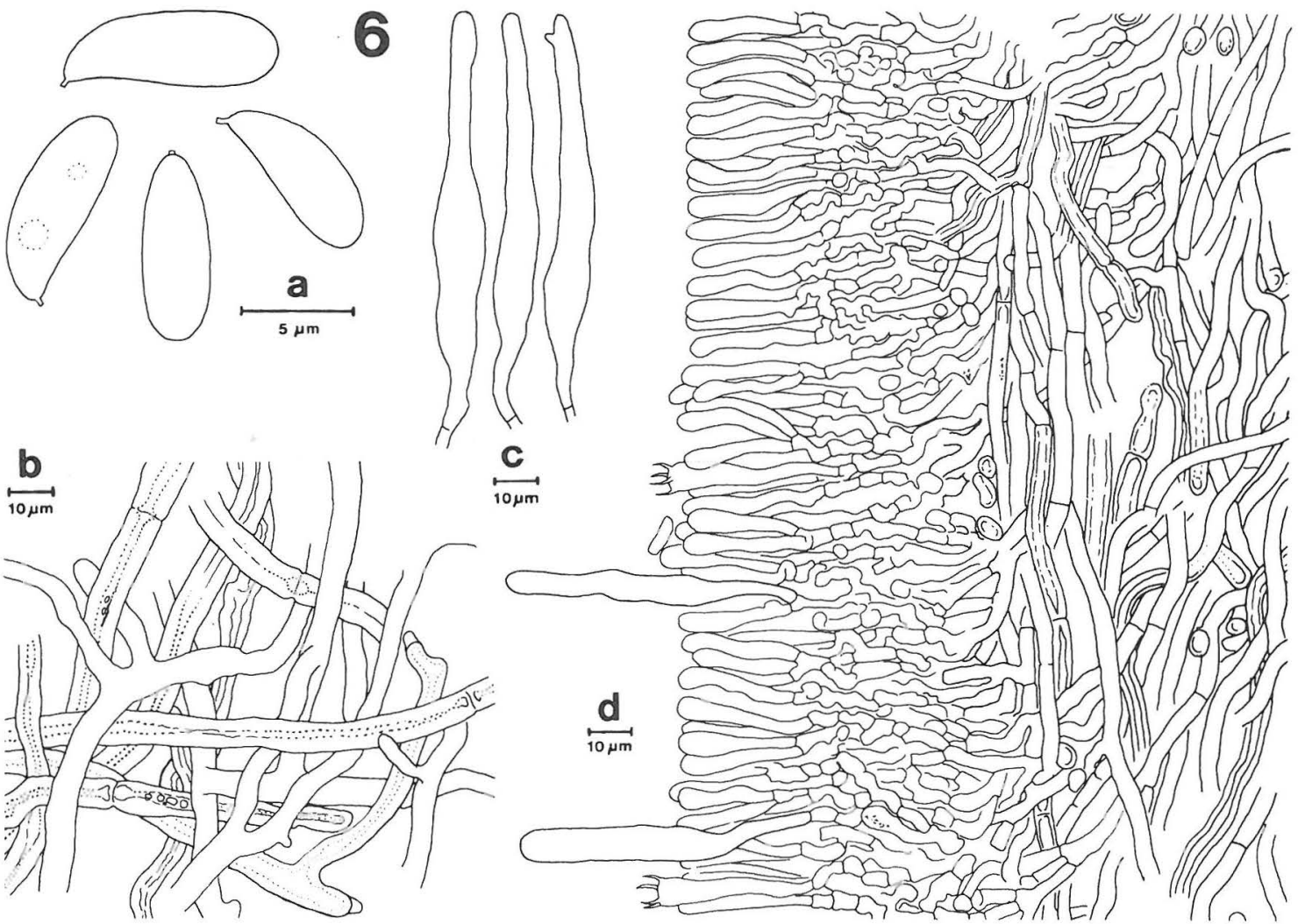

Fig. 6. Pycnoporellus alboluteus. a) spores, b) hyphae from subiculum, c) cystidioles, d) dissepiment in vertical section (specimen Niemelä 1552 \& Kotiranta, T.N.).

darker and more intense deep in the tube cavities. Bruised parts (e.g. tube mouths) darkening in young stage, sometimes into coffee brown, in adult stage becoming translucent and greasy-looking, in final stage not changing. Subiculum orange yellow or saffron. Colours fading only a little in properly dried specimens. Surface changing into pink to purple and subiculum into blood or reddish black in $\mathrm{KOH}$.

Spores (7.0-) 7.9-10.0 (-11) $\times(2.5-) 2.8-3.5$ (-4.0) $\mu \mathrm{m}$, single, narrowly ellipsoid to cylindrical, with rounded apex and slightly arcuate towards apiculus, smooth, very thin-walled, hyaline, nonamyloid, indextrinoid, acyanophilous. Apiculus distinct, ca. $0.7 \times 0.7 \mu \mathrm{m}$. (Fig. 6)

Basidia $32-40 \times 5.8-6.1 \mu \mathrm{m}$, narrowly clavate, four-spored; sterigmata $4-5 \mu \mathrm{m}$, thinning evenly towards apex. Basidioles similar in shape, $29-38 \times$ $4-5 \mu \mathrm{m}$. Cystidioles common, $(40-) 75-120 \times$ 7-11 $\mu \mathrm{m}$, hyaline, thin-walled, with rounded and rarely forked apices, arising from subhymenium.
Subhymenium $20-40 \mu \mathrm{m}$, not well delimited, formed by thin-walled, richly branched hyphae $2-4$ $\mu \mathrm{m}$ in diam.

Hyphal system monomitic. Generative hyphae simple-septate, of even tichness, flexuose, little or moderately branched, wall thickness very variable, depending on age. Hyphae hyaline or yellowish in lactophenol or Melzer's reagent, unstained in Cotton Blue, in $\mathrm{KOH}$ variable; old hyphae covered by scattered needle-like crystals, $2-4 \mu \mathrm{m}$ long and solube in $\mathrm{KOH}$. Tramal hyphae (3-) 4-7 $\mu \mathrm{m}$ in diam., interwoven to subparallel, in young fruit bodies thin-walled and not staining in $\mathrm{KOH}$, in old specimens thick-walled to subsolid and staining faint pink in $\mathrm{KOH}$. Hyphae of subiculum (4-) 5-8 (-9) $\mu \mathrm{m}$, thicker and unbranched, often in strands, intermixed with ramified and freely oriented branches, with somewhat thickened (young) to subsolid (old) walls and staining faint pink to deep orange-red in $\mathrm{KOH}$. 


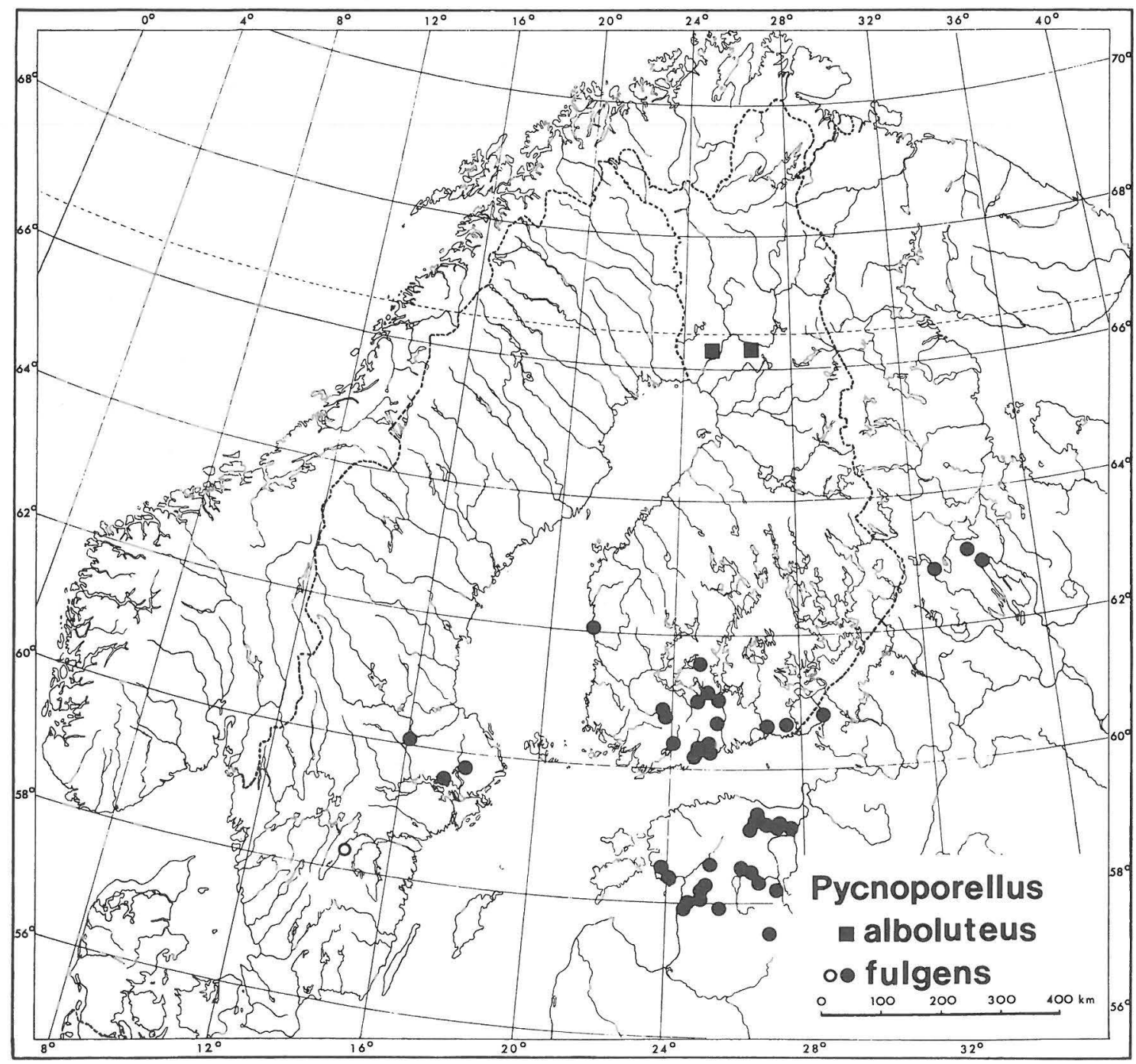

Fig. 7. Distributions of Pycnoporellus alboluteus and $P$. fulgens in North Europe. Based on the specimens examined, except the distribution in Estonia, which is according to E. Parmasto (in litt.). The open circle indicates the holotype locality of $P$. fulgens.

In Fennoscandia on dead, preferably decorticated trunks of Picea abies, one record from Alnus incana. Grows in luxuriant, old spruce or spruce-mixed forests in the northern boreal zone. A very rare species.

\section{Distribution}

\section{Specimens examined}

Finland. Pohjois-Pohjanmaa. Rovaniemi, Viiri, Hyypiönkivalo, Picea abies, 1967 Hintikka \& Korhonen 8281 (HFR). Rovaniemi, Pisavaara National Park: sine loco, 1974 Anonymous (HFR); Sorvanulikka, P. abies, 1979 Alava 18731 (TUR); Liljalaki, P. abies, 1979 Kotiranta 1323, 1324, 1346 \& Niemelä 1551, 1552, 1568 (H, H.K., T.N.), Alnus incana, 1979 Niemelä 1543 \& Kotiranta (T.N.), P. abies, 1980 Kotiranta 2193 \& Niemelä 2077, 2085 (H, H.K., T.N.). Tervola, Pisavaara National Park, Liljalaki, P. abies, 1980 Kotiranta 2200 \& Niemelä 2090 (H.K., T.N.).

Poland. Hajnówka. Bialowieża National Park, P. abies, 1969 Niemelä 344 (H, T.N.).

U.S.S.R. Georgian S.S.R. (see type of Irpex woronowii, S).

U.S.A. New York. (see type of Lenzites sepiaria var. dentifera, NYS). - Colorado. (see type of $P$. alboluteus, 
NY). - Washington. Olympic Peninsula, Soleduck, Tsuga, 1957 Lowe $8054(\mathrm{H})$.

Canada. British Columbia. Vancouver I., Oyster River, Picea sitchensis, 1938 Mounce 8263 (H, OULU).

The only records of this species from North Europe are from two areas in northern Finland (Fig. 7). The eastern and oldest find (Hintikka 1970) is represented by a single collection. The other collections are from the Pisavaara National Park, where $P$. alboluteus occurs on two mountain slopes, Sorvanulikka and Liljalaki, circa $4 \mathrm{~km}$ from each other, between 100 and 160 metres above sea level. All these localities are on the southern border of the northern boreal zone (Ahti et al. 1968).

$P$. alboluteus seems to be a rarity everywhere in Eurasia. In Europe it is known from the Bialowieża National Park in Poland (Domański 1959), from eastern Czechoslovakia (Kotlaba \& Pouzar 1963) and from Yugoslavia (Tortić \& Jelić 1974). In the U.S.S.R. it has been recorded from the Georgian S.S.R. (in SW Caucasus, Tortić \& Jelić 1974, Parmasto \& Parmasto 1979), the Komi A.S.S.R. (Parmasto 1963, Parmasto \& Parmasto 1979), Ukrainan S.S.R. (Bondarcev 1953, Kotlaba \& Pouzar 1963), southern Urals (Stepanova-Kartavenko 1967) and Tomsk Region (Bondarcev 1953, Kotlaba \& Pouzar 1963). No records were found from the eastern U.S.S.R. or elsewhere in East Asia.

In North America the southernmost records are from the mountains of the western U.S.A.: New Mexico (Gilbertson et al. 1975), Arizona (Gilbertson \& Budington 1970, Gilbertson et al. 1974), Colorado (Murrill 1907, Shope 1931), California and Utah (Overholts 1953). From there it extends north to British Columbia and Alaska (Baxter 1938, Overholts 1953). In the eastern, evidently separate distribution area the species is rare and reported only from Michigan, New York, Ontario and Quebec (Baxter 1938, Overholts 1953, Lowe 1966).

Generally, $P$. alboluteus is much rarer than $P$. fulgens, and occurs in somewhat cooler areas: at more northern latitudes and higher up in the mountains.

\section{Ecology and phenology}

The growth sites of $P$. alboluteus were studied in the Pisavaara National Park, 'one of the very best research areas for field mycology in Fennoscandia' (Eriksson \& Strid 1969). The finds were made on the central and lower parts of the gentle north-eastern slopes of Mount Liljalaki, evidently not studied by mycologists before. P. alboluteus was growning in depressions which are well-drained throughout the growing season, housing temporary rivers during the spring, and a thick, long-lasting snow cover in the winter.

The vegetation on these slopes is most luxuriant (Fig. 8; cf. Teivainen 1949, 1952). It consists of virgin, dense and very productive spruce (Picea abies) forest interspersed with large single individuals of Populus tremula, and with scattered Betula pubescens, Alnus incana and Salix caprea in more moist, open places. Tall grasses and herbs are abundant. Common grasses are Calamagrostis purpurea ssp. phragmitoides, Melica nutans, Milium effusum and Elymus caninus. There are numerous herb species, some of the most prominent being Actaea erythrocarpa, Cicerbita alpina, Cirsium heterophyllum, Filipendula ulmaria and Geranium sylvaticum. The most common ferns are Gymnocarpium dryopteris and Thelypteris phegopteris. Dwarf shrubs and mosses are few.

The dense tree stand and the virgin character of the forest ensure a constant and abundant supply of wood of different ages for the wood-rotting fungi. Therefore it is not surprising that many rare and demanding species of the polypores were found growing in the vicinity of $P$. alboluteus: among others Amylocystis lapponica, Fomitopsis rosea, Junghuhnia collabens, Piptoporus pseudobetulinus, Poria crustulina and $P$. placenta.

The fruit bodies were found on large, decorticated trunks of spruce, and the trunk of Alnus incana was also a relatively big one. The fungus grows mostly in the central parts of the trunks, often on the undersides if the trunk is not very close to the ground. These fruit bodies are resupinate, and may extend along the trunk up to two metres long. On the logs closely attached to the ground, the fruit bodies form on the lateral or even the upper sides, then consisting of ruff-like nodules. Most often the fructifications emerge from fissures or clefts in the trunk, or from under the bark at the edge of the decorticated wood (Fig. 2). The wood under the fruit bodies is very hard.

Many other wood-decaying fungi were found on the same trees together with $P$. alboluteus (Fig. 8), but no association such as that of $P$. fulgens with Fomitopsis pinicola was observed.

The American authors repeatedly report that the species grows near the receding snowline, or during the winter and spring on snow-covered trees. In Europe such behaviour has not been observed, and the growth period begins in early autumn. However, there are no records on how long the fructification continues, and the occurrence of the species in depressions with a long-lasting snow cover clearly 


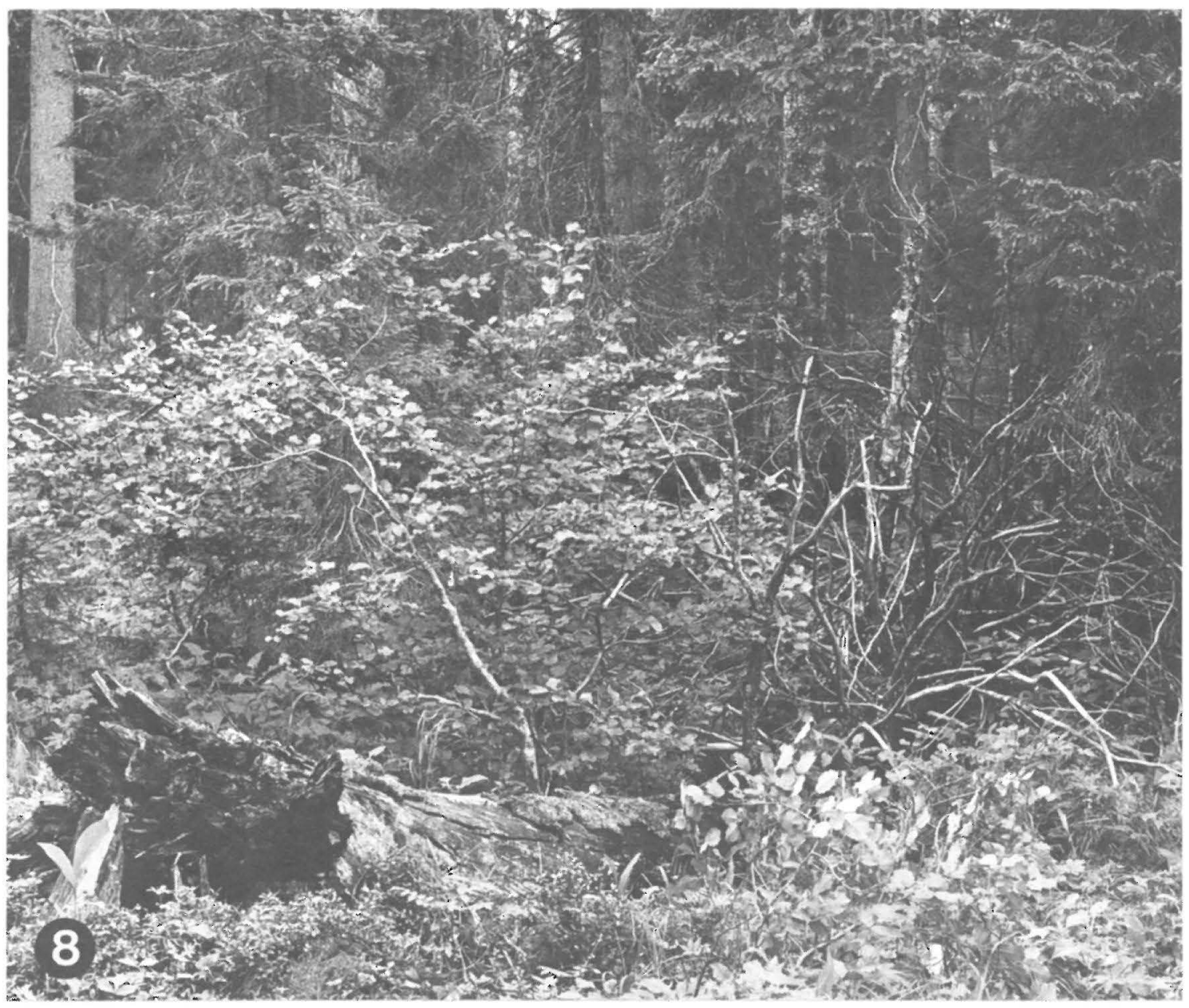

Fig. 8. Growth site of Pycnoporellus alboluteus in the Pisavaara National Park in northern Finland. Large fruit bodies were collected from the fallen spruce in the foreground. The same tree trunk also bore Amylocystis lapponica, Amyloporia xantha, Fomitopsis pinicola, F. rosea, and Poria placenta.

suggests ecological requirements similar to those in North America. It should also be noted that the mycelia of $P$. alboluteus readily fructify in storage cultures kept in $+5^{\circ} \mathrm{C}$.

This is the first record of $P$. alboluteus growing on the hardwood genus Alnus, and may be the first European record of the occurrence of the species on an angiosperm. There are also very few such records from America: from Populus tremuloides (Gilbertson et al. 1974) and P. trichocarpa (Baxter 1938). The report of Bresadola (1920, sub n. Irpex woronowii) from Fagus is based on misidentification of the host (Tortić \& Jelić 1974). In the literature the species has been reported most often from Picea $(P$. abies, $P$. glauca, $P$. engelmannii, P. abies subsp. obovata and
$P$. pungens). The other hosts recorded include $A$ bies (A. alba, A. concolor, $A$. nordmanniana and $A$. lasiocarpa), Larix, Pinus, Pseudotsuga and Tsuga.

\section{Cultural characters}

The cultures of $P$. alboluteus have been studied by David (1969) and Stalpers (1978), and therefore only some brief remarks will be added here. They are based on a strain isolated from the fruit body of the collection Niemelä 1551 \& Kotiranta.

The mycelium of $P$. alboluteus grows rapidly on malt agar. At $24^{\circ} \mathrm{C}$, the radial growth is (23-) $32-42 \mathrm{~mm}$ in a week, and $75-\mathrm{mm}$ Petri dishes with 
side inoculations become covered with mycelium in two weeks. At $35^{\circ} \mathrm{C}$ no growth took place.

The culture changes very little with age. At the age of one week it is very delicate, translucent, colourless and without zones. The hyphae grow submerged, forming an even margin. Aerial hyphae appear at the end of the second week, forming thinly downy, white, translucent mycelium, which is thicker around the dish margins. After several weeks the aerial mycelium becomes pale brown-orange in colour.

The generative hyphae are $3-6 \mu \mathrm{m}$ in diam., thinwalled, hyaline, with simple septa and few (young cultures) to frequent branches, of even thickness except for the slightly swollen tips and a few almondshaped swellings in old hyphae. In $\mathrm{KOH}$ the hyphae stay unstained, or assume a weak pinkish hue.

At $24^{\circ} \mathrm{C}$ no sporulation could be observed. However, in storage cultures kept at $+5^{\circ} \mathrm{C}$, in the dark, distinct fruit body formation began within half a year (Fig. 5). The fruit bodies on agar slants were small, foliose, and with the typical colouration of natural fruit bodies. In the microscope also, they closely resembled true dissepiments, having hyphae which stain red in $\mathrm{KOH}$, bearing a hymenium with basidia, basidioles and cystidioles, and producing typical basidiospores.

\section{Notes on $\mathbf{P}$. alboluteus}

The species is unmistakably distinguished from all the other species of the polypores and the irpicoid and hydnaceous Aphyllophorales by its colour, coarse and dentate pores, and overall appearance. Although it is macroscopically quite different from $P$. fulgens, the close relationship of the two species is evident in the microscopical structure and the chemical colour reactions. The reddening in $\mathrm{KOH}$ is distinct, especially in the subiculum, though it is generally weaker in $P$. alboluteus than in $P$. fulgens.

The great variability in the hyphal wall thickness observed in $P$. fulgens exists in $P$. alboluteus as well. The spore length also varies considerably, though not so much as in P. fulgens. Kotlaba and Pouzar (1963) compared the spore lengths in the American and European material, and observed a difference great enough to raise the question whether the name $P$. alboluteus actually covers two species. They found, however, collections with intermediate measurements. The Fennoscandian material falls within this group with intermediate spore measurements, and in my opinion the differences only reflect the general variability in the microscopical characters of the genus Pycnoporellus.

Some macroscopical differences, however, remain between the American and European collections. In America $P$. alboluteus is reported to form typical pilei with a tomentose upper surface. I have not found such pilei in the material from Europe. The species forms a much thicker subiculum in North America (visible e.g. in the type) than in Europe, as already observed by Kotlaba and Pouzar (1963).

\section{Pycnoporellus fulgens}

Hydnum fulgens Fries, Öfvers. Kongl. Vetenskaps-Akad. Förhandl. 9: 130. 1852. Holotype: Hydnum fulgens Fr. (Sweden, Östergötland,) Omberg, 1851 C.A. Holmgren (handwriting of E. Fries, UPS, selected as the 'neotype' by Ryvarden in herb. 1974; isotype S). - Pycnoporellus fulgens (Fr.) Donk, Persoonia 6: 216. 1971.

Polyporus fibrillosus Karsten, Sydvestra Finlands polyporeer: 30. 1859. Lectotype: Trametes fibrillosa, (Finland, Etelä-Pohjanmaa,) Sideby, ad trunc. Populi, junio 1859 P.A. Karsten 1896 (H, selected as the 'type' by Lowe 1956). - Pycnoporellus fibrillosus (Karst.) Murrill, Bull. Torrey Bot. Club 32: 489. 1905.

Polyporus aurantiacus Peck, N.Y. State Mus. Ann. Rep. 26: 69. 1874. Holotype: Polyporus aurantiacus Pk., (U.S.A., New York,) Schoharie Co., Richmondville, C.H. Peck (NYS).

Ochroporus lithuanicus Błoński, Hedwigia 28: 280-281. 1889. Lectotype: Polyporus lithuanicus BYoński, Polonia, Lithuania, BiaYowieża, ad Quercum, julio 1887 Fr. BYoński, Herb. Karsten 2226 (H, selected here).

See discussions in the section Type studies. For further combinations see Donk (1974).

Not Polyporus shiraianus P. Henn., Bot. Jahrb. 28: 269. 1900. The type (from Japan, not seen) is a species of Favolus (Polyporus), cf. Donk (1974: 363). The error regarding the synonymy is due to the report of Murrill (1907), who evidently studied not the type but another specimen so named (Lloyd 1922). This error has been widely accepted, e.g. by Pilát (1936-1942) and Bondarcev (1953).

Fruit body annual, mostly solitary but sometimes in imbricate groups of two to four. Consistency soft fibrous, spongy or sodden when fresh, rigid, friable and light-weight when dry, contracting only slightly when drying. Taste mild.

Mostly sessile, less often effused-reflexed, seldom resupinate. Pileus $2-10 \mathrm{~cm}$ wide, $4-10 \mathrm{~mm}$ thick and thickness in umbonate base up to $20 \mathrm{~mm}$, projecting $15-30(-50) \mathrm{mm}$ from substrate. Effused parts up to $10 \times 6 \mathrm{~cm}$ but mostly smaller than adjacent pilei, 3-5 $\mathrm{mm}$ thick. Pileus at first nodular, soon shelf-shaped and semicircular, sometimes with a distinct umbo but mostly narrowly attached, effused parts easily peeled from substrate. Margin of fully grown fruit bodies thin, sharp and often slightly involute when drying (Figs. 9-10).

Upper surface orange-red, in very old collections darkened to orange-rust, concolorous but with slight 

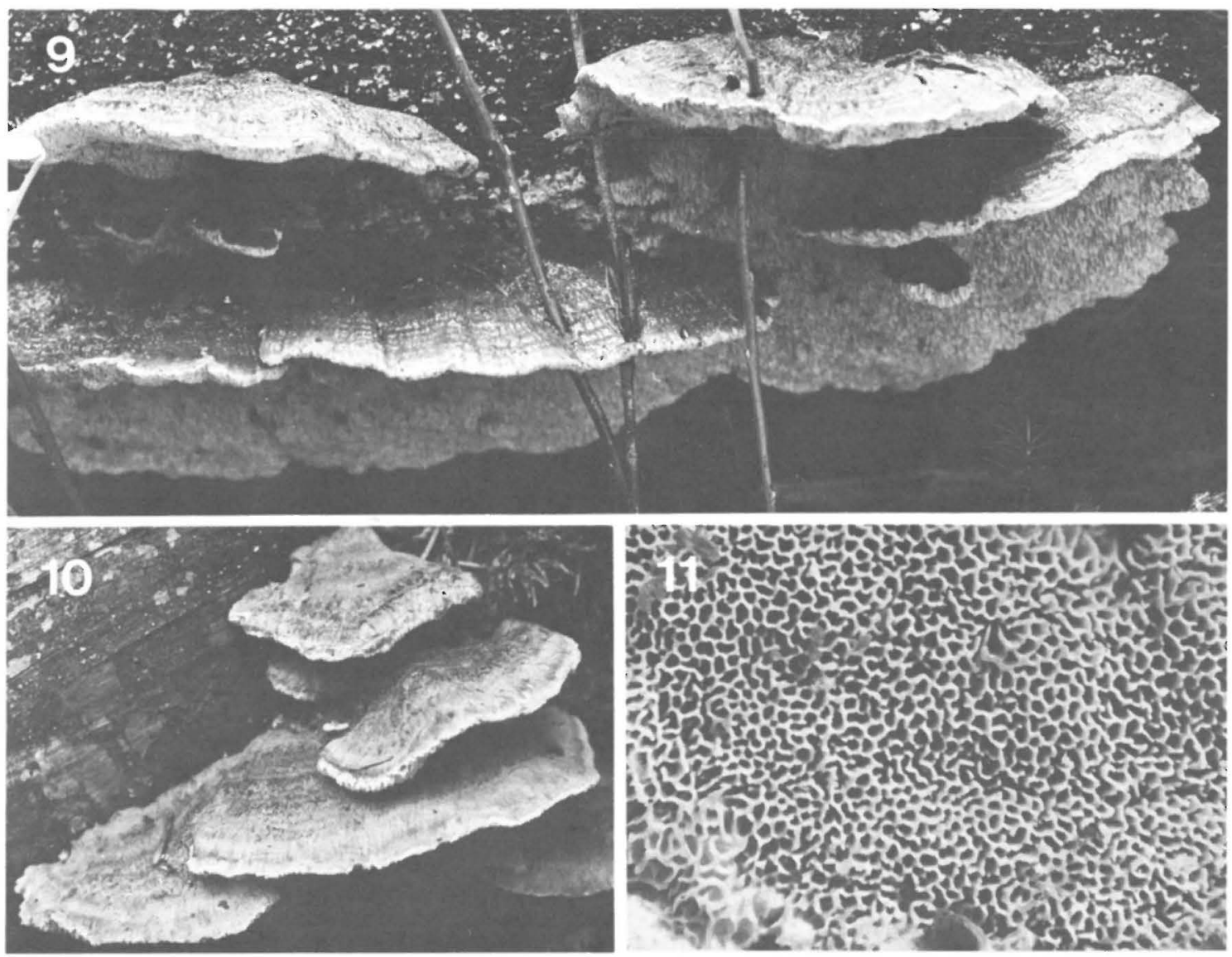

Figs. 9-11. Pycnoporellus fulgens. - 9: Effused-reflexed fruit bodies (Finland, Sipoo, Picea abies, 1976 Niemelä, $\times 0.8$ ). - 10: Pileate fruit bodies (Finland, Vantaa, P. abies, 1977 Niemelä 1280, $\times 0.7$ ). -11 : Pores of an effused part (Finland, Vihti, 1978 Kotiranta $1504, \times 5)$.

structural zonation, first pubescent, in mature stage softly fibrillose, lowly hirsute around attachment. No cortex or pellicle.

Pore surface rough, of about the same hue as above, but lighter, pale orange to apricot, glancing. Pores first $(1-) 2-3$ per $\mathrm{mm}$, roundish or angular, mouths entire or lowly toothed; in later stage pores fusing together, sinuous or irregular, up to $1-2 \mathrm{~mm}$ diam. in longest dimension, dentate and finally lacerate (Fig. 11).

Context in section of the same colour as upper surface or somewhat lighter, homogeneous, concolorous or with faint zonation in thick base, $2-5 \mathrm{~mm}$ thick or up to $18 \mathrm{~mm}$ thick in umbonate base. Tubes in section saffron to apricot, or brick to blood red in old or badly preserved specimens, tubes 2-5 mm long.

Colours fading only a little in properly dried specimens. All parts, especially upper surface and context, rapidly stained intense dark wine red or reddish black by $\mathrm{KOH}$.

Spores (5.0-) 5.9-10.0 (-15.0) $\times(2.5-)$ $2.9-4.0(-4.5) \mu \mathrm{m}$, single narrowly ellipsoid, longer spores with pointed ends and arcuate towards apiculus, smooth, very thin-walled, hyaline, nonamyloid, indextrinoid, acyanophilous, contents at the end of sporulation colouring faint pink in $\mathrm{KOH}$. Apiculus distinet, ca. $0.8 \times 0.8 \mu \mathrm{m}$. The size variation in the spores is exceptionally great, even within a single collection. (Fig. 12)

Basidia 20-30 × 4.5-5.5 (-6.0) $\mu \mathrm{m}$, narrowly clavate; sterigmata (3.5-) 5-7 $\mu \mathrm{m}$ long, thinning evenly towards apex, mostly 4 per basidium, but fairly often 2 (rarely 1 or 3 ). Basidioles similar in shape, but seldom over $20 \mu \mathrm{m}$ long. Cystidioles rare to scattered, (27-) $35-50 \times 3-5.5 \mu \mathrm{m}$, hyaline, 
thin-walled, with rounded tips, projecting $25-30 \mu \mathrm{m}$ above hymenium, most common near the bottoms of the tubes, arising from subhymenium. In old fruit bodies also a few thick-walled pointed cystidioles ('pseudosetae') $40-50 \times 5-8 \mu \mathrm{m}$, arising from trama and staining light reddish in $\mathrm{KOH}$. Hymenial elements form a fairly dense palisade.

Subhymenium 6-10 $\mu \mathrm{m}$, not well delimited, formed by thin-walled, richly branched hyphae 2-4 $\mu \mathrm{m}$, in diam., cells mostly $3-8 \mu \mathrm{m}$ long.

Hyphal system monomitic. Generative hyphae simple-septate, of even thickness, flexuose, moderately branched, wall thickness very variable in different parts of fruit body and depending on age, wall thickening characteristically starting near the septa (Fig. 12). Hyphae yellow in Melzer's reagent, unstained in Cotton Blue, in $\mathrm{KOH}$ variable; old hyphae covered by granule- or needle-like $(1-3 \mu \mathrm{m}$ long) crystals, visible in, for instance, lactophenol but soluble in $\mathrm{KOH}$. Tramal hyphae $2.5-5.5 \mu \mathrm{m}$ in diam., subparallel, near tube mouths thin-walled and not staining in $\mathrm{KOH}$, in upper trama walls $0.3-0.6$ $\mu \mathrm{m}$ (young fruit bodies) to $1.5 \mu \mathrm{m}$ (old specimens) thick and staining pale pink in $\mathrm{KOH}$. Hyphae of context 3-9 $\mu \mathrm{m}$ in diam., loosely arranged, thicker hyphae, often forming strands, intermixed with freely oriented thinner branches, thin-walled (young) to subsolid (old) and staining bright orange-red in $\mathrm{KOH}$. Hyphae in surface hairs up to $10 \mu \mathrm{m}$ in diam., subsolid.

In Fennoscandia mostly on dead Picea abies, seldom Pinus sylvestris, Populus tremula and Betula sp., very often growing on wood first decayed by Fomitopsis pinicola. A rare south-eastern species. Prefers old, dense, moist spruce or spruce-mixed forests.

\section{Distribution}

\section{Specimens examined}

Sweden. Östergötland. Omberg, 1851 Holmgren (type of Hydnum fulgens, UPS; isotype S). - Södermanland. Vallby, Picea abies, 1843 Lindblad (S, UPS). Västmanland. Norberg, P. abies, 1979 Hjortstam 10816, 10817 (GB). - Uppland. Knivsta, 1979 Jonsson (S).

Finland. Varsinais-Suomi. Vihti, P. abies with Fomitopsis pinicola, 1978 Kotiranta (H.K., T.N.); 1979 Kotiranta 1504-1506 (H.K.). - Uusimaa. Espoo, P. abies, 1958 Kujala 327, 328 (HFR); $P$. abies, 1958 Kujala \& Eriksson 1615 (GB); Betula with $F$. pinicola, 1966 Niemelä 7412 (HFR, T.N.). Mäntsälä. P. abies, 1979 Laine (HFR). Sipoo, $P$. abies with $F$. pinicola, 1971 Niemelä 424 (T.N.); 1972 Niemelä 453 (T.N.); 1976 Niemelä (OULU). Tuusula, $P$. abies, 1953 Kujala 329 (HFR). Vantaa, P. abies, 1977 Niemelä 1280 (T.N.); 1978 Niemelä (T.N.). - EteläKarjala. Vehkalahti, Pinus sylvestris, 1963 Valleala 330
(HFR); P. abies, 1977 Fagerström (H). - Etelä-Häme. Hollola, $P$. abies with $F$. pinicola, 1979 Haikonen $284(\mathrm{H})$. Janakkala, $P$. abies with $P$. pinicola, 1979 Saarikko $1(\mathrm{H})$. Lammi, $P$. abies with $F$. pinicola, 1972 Niemelä 444 (T.N.). Längelmäki, $P$. abies with $F$. pinicola, 1977 Niemelä 1297 (T.N.). Tammela, P. abies, 1869 Karsten 1899-1902 (H). - Etelä-Pohjanmaa. Sideby, Populus tremula, 1859 Karsten 1896 (type of Polyporus fibrillosus, H), 1897-1898 $(\mathrm{H})$, Fungi Fenn. Exs. $311(\mathrm{H})$.

U.S.S.R. Leningrad Region. Vyborg, P. abies, 1891 Thesleff (H); Populus tremula, 1891 Thesleff $(\mathrm{H})$. Karelian A.S.S.R. Porajärvi, Pinus sylvestris, 1941 Carpelan (H). Semsjärvi, P. abies, 1942 Carpelan (H). Between Kontiovaara and Tšopina, P. abies, 1943 Kari 61727 (TUR). - Estonian S.S.R. Tartu, P. abies, 1953 Parmasto 331 (HFR). - Ukrainan S.S.R. 'Carpatorossia, Trebušany', P. abies, 1937 Pilát $(\mathrm{H})$.

Poland. Hajnówka. (see type of Ochroporus lithuanicus, H); Białowieża, Betula, 1969 Niemelä (H); P. abies, 1969 Niemelä (H, T.N.). - Warsaw. Populus, Błoński (S).

Czechoslovakia. Slovakia. Kremnické rudohorie, Badinský prales, Abies alba with $F$. pinicola, 1973 Kotlaba, Pouzar \& Niemelä (T.N.). Slovenské rudohorie, Dobrocký prales, $P$. abies, 1973 Kotlaba, Pouzar \& Niemelä $(\mathrm{H})$.

U.S.A. New York. Wanakena, Picea, 1958 Lowe 8526 (H). Richmondville (see type of Polyporus aurantiacus, NYS).

Canada. British Columbia. Vancouver I., Pseudotsuga menziesii, 1967 Eriksson \& Eriksson 7943, 8142 (GB). McLeod Lake District, Picea glauca, Eriksson \& Eriksson 12842 (GB). - Ontario. Petawawa Forest Exp. Sta., Abies balsamea, 1942 Groves 10909 (HFR 332).

The distribution of $P$. fulgens in North Europe is distinctly south-eastern (Fig. 7). It is not known from Norway or Denmark (Ryvarden 1978), and in Sweden it occurs very rarelyn the south-eastern parts only. The species is locally relatively frequent in some suitable forests of southern Finland. The fact that it has been collected from many new Finnish localities during recent decades, suggests that it may have become less rare. This is remarkable because the forests favourable to $P$. fulgens have surely diminished over the years. Further, there is no reason to believe that the species has been missed by the collectors earlier: $P$. fulgens is a showy species which has certainly always caught the attention of mycologists.

The localities of $P$. fulgens in Fennoscandia fall within the southern boreal and hemiboreal zones. The northernmost localities in Soviet Karelia (Fig. 7; also listed by Šubin \& Krutov 1979) lie at about the northern limit of the southern boreal zone (Ahti et al. 1968), and these are among the northernmost localities of the species within its total distribution area. The distribution in North Europe is clearly determined by the climate, because the main host, Picea abies, is common in the northernmost parts of 

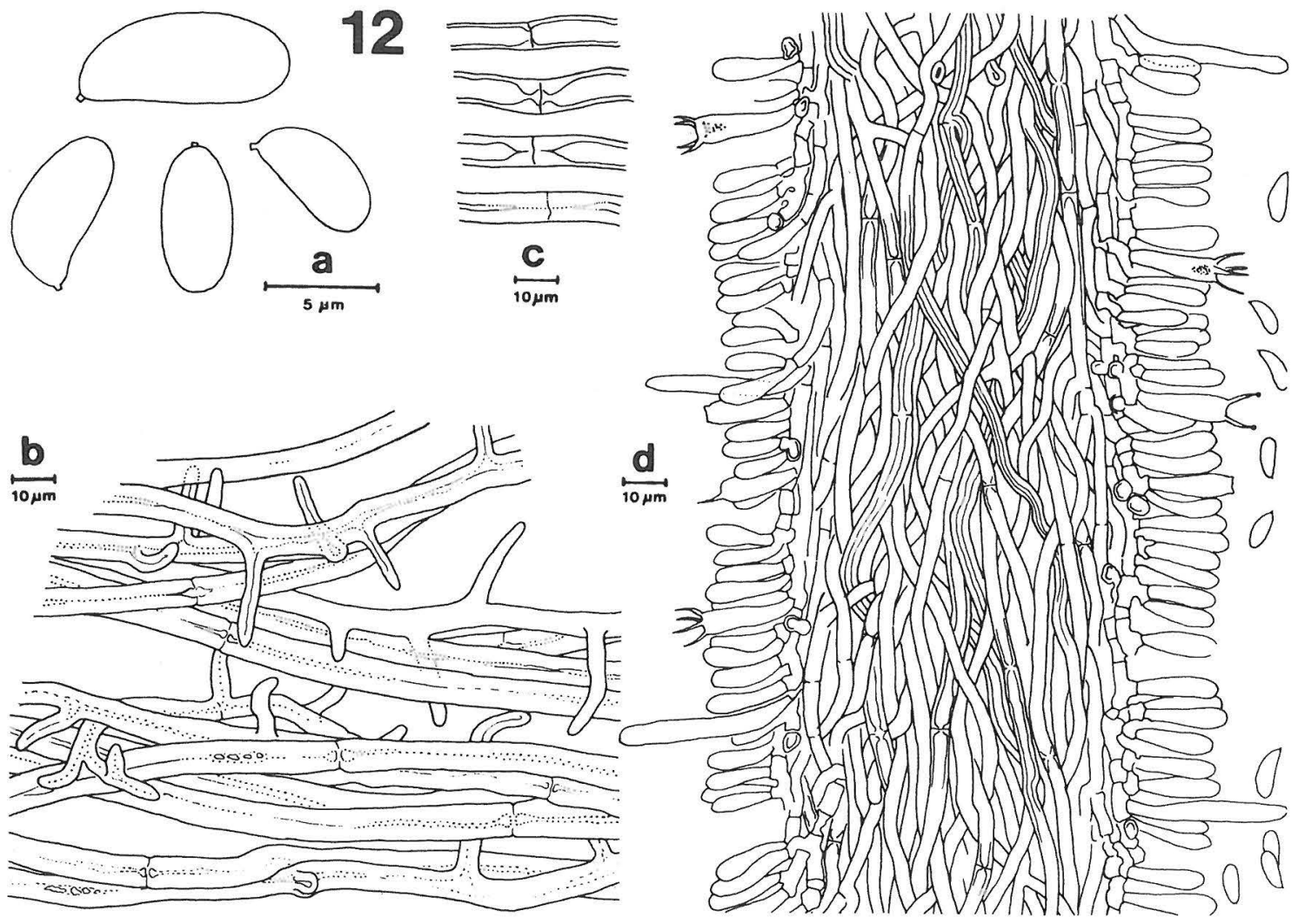

Fig. 12. Pycnoporellus fulgens. a) spores, b) section from upper context, c) septa in the hyphae of the lower context at various stages of wall thickening, d) dissepiment in vertical section (specimen Niemelä 424, T.N.).

this region, and suitable forest types were even commoner in the central - northern parts.

South of Fennoscandia in Europe, the species is known from several localities in the Estonian S.S.R. (Parmasto \& Parmasto 1979 and personal communication, see map), and the Lithuanian S.S.R. (Mazelaitis 1976) of the Soviet Union. From Poland it has been recorded at least from the Białowieża (Domański et al. 1973) and the Świety Krzyś (Kotlaba \& Lazebníček 1967, Lisiewska 1979) national parks. In Czechoslovakia the species is fairly frequent in some montane Moravian and Slovakian areas, growing mostly in submontane and montane virgin beech - fir forests between 400 and 900 metres above sea level (Kotlaba in litt., Kotlaba \& Pouzar 1963). Bourdot and Galzin (1927) reported it from Hungary, but this information may have been based on the record of Bresadola (1897) from Mount Sitno, which now belongs to south-eastern Czechoslovakia. Tortić and Jelić (1969) have recorded two montane localities in Yugoslavia, and they (and also Pilát 1936-1942) mention its occurrence in Austria. Barbas (1980) makes a report from eastern France. It is remarkable that there are no records of the species in westernmost Europe. Their absence suggests a rather continental distribution, but this does not accord with the total distribution of the species.

Further records from the European U.S.S.R. were made in the Byelorussian S.S.R. (Komarova 1964), the Ukrainan Carpathians and eastwards between the $50^{\circ}$ and $60^{\circ}$ latitudes (Bondarcev 1953) to the Komi A.S.S.R. (Parmasto 1963) and the Urals (StepanovaKartavenko 1967). Very few notes exist of the species in the Asian U.S.S.R. There is an isolated montane occurrence in the Caucasus (Bondarcev 1953), and it has been reported from the mountains of eastern Kazakhstan (Švarcman 1964) and from the Krasnoyar'sk' Territory (Parmasto \& Parmasto 1979). In the Soviet Far East it has been recorded from the Amur, Primorye and Sakhalin Regions, the 
Khabarovsk Territory and the Yakut A.S.S.R. (Lyubarskij \& Vasil'yeva 1975, Parmasto \& Parmasto 1979).

Some authors (Murrill 1907 sub n. Polyporus shiraianus, Lloyd 1922 sub n. P. aurantiacus, Pilát 1936-1942, Bondarcev 1953) report $P$. fulgens from Japan, but the species is not mentioned in the local manuals of Kawamura (1955) or Imazeki and Hongo (1965).

In North America P. fulgens has two distributional areas. In the western part of the continent the species has been collected mainly from montane areas in the Cordillera, from Colorado (Shope 1931) north to Alaska (Overholts 1953). The more coherent eastern distributional area embraces Manitoba and the Great Lakes region, extending eastwards to the maritime coastal areas, where the easternmost find was made in Newfoundland and southwards along the Appalachian Mountains to West Virginia (Overholts 1953, Gilbertson \& Lombard 1976).

Thus the distribution of $P$. fulgens is mainly southern boreal - hemiboreal. The southern collections made in Europe, Central Asia and North America originate from mountainous areas climatically roughly corresponding to the hemiboreal zone. Although the European occurrence suggests that the species is slightly continental, it extends to the humid coastal areas in both eastern Asia and America, and, moreover, it seems to be widely absent from the continental inner parts of North America and northern Asia. The total distribution is thus slightly oceanic in character.

\section{Type studies}

The long-forgotten specific name fulgens was reestablished by Donk (1971), who thus broke the tradition of using the name $P$. fibrillosus Karsten. This was a sound solution: the description of Fries (1852) is quite clear, and the type material exists. In the description Fries mentions one specimen only, with which the collection preserved in the Fries herbarium (UPS) fits in all respects, including the locality, collector and the year. So there is every reason to treat the 'Omberg, 1851 C.A. Holmgren' collection as the holotype. The fragment of this specimen (in S) was separated much later, evidently by Lars Romell, and can thus be treated as an isotype.

The type material of $P$. fibrillosus (Karsten 1859) consists of several specimens, the collections made by Karsten (nos. 1896-1898) and the distributed exsiccata (Karsten 1866). They all represent the species in question. Lowe (1956 and in herb.) selected the type from this material (specimen no. 1896, H) but did not indicate its lectotype status.

Two original collections of Ochroporus lithuanicus Bloński were found. They both represent $P$. fulgens. The specimen in the Bresadola herbarium (S) bears no year and was collected in Warsaw. Bresadola (1897) mentioned 'authentic specimens' he had seen, but did not refer to any particular specimen. The specimen which Bloński sent to Karsten (Herb. Karsten no. 2226, cf. Karsten 1889) was collected well before the description, and its locality ('Lithuania, Białowieża') fits better with the specific epithet. Therefore the latter is selected here as the type. In the description BYoński (1889) mentions several host tree species, and so this specimen must be treated as the lectotype only.

\section{Ecology and phenology}

In Fennoscandia, $P$. fulgens favours virgin or old spruce or spruce-mixed forests with a dense tree stand. In most cases the forest has been slightly swampy or paludified, with a thick cover of moss (especially Sphagnum species) on the ground. Often the collection site has been in the vicinity of a brooklet, pond, lake or seashore. All this indicates that the species grows best in environments where the microclimatic humidity is high.

Most collections were made from fairly big trees, fallen some years earlier and preferably partly decorticated. Some fruit bodies were collected from the broken base of the tree, but they were often taken from the intact central parts of the trunk. But the most remarkable feature in the ecology of the species is, that in very many cases (all those studied by me) $P$. fulgens was growing on a tree already decayed by Fomitopsis pinicola. Characteristically, F. pinicola first kills the tree and causes its fall, then fruits and dies. It is after this that $P$. fulgens appears, the fruit bodies often developing close to the dead carpophores of $F$. pinicola, or arising straight from them. This is the situation in Fennoscandia: I have also observed the same phenomenon in Poland and in the Czechoslovakian mountains, where the species was growing on Abies alba first decayed by $F$. pinicola. Whether this is the course of events in the other parts of the distribution area is not known. I have not found any reference to this mutualism in the literature (except in Niemelä 1980).

The host tree species seems to be less important to $P$. fulgens than is the preceding decayer fungus, though it clearly favours conifers. In Fennoscandia the occurrence on different hosts was roughly as follows: 


$\begin{array}{lc}\text { Picea abies } & 75 \% \\ \text { Pinus sylvestris } & 10 \\ \text { Populus tremula } & 10 \\ \text { Betula species } & 5\end{array}$

Conifers mentioned in the literature are Abies alba, A. sibirica, Larix gmelinii, L. decidua, Picea abies, $P$. glauca, $P$. jezoensis, $P$. rubens, Pinus koraiensis and $P$. sylvestris. The hardwood genera most often mentioned are Acer, Betula, Populus and Quercus, but everywhere coniferous trees seem to be more common as the hosts. Only Neuman (1914 sub. n. Polyporus aurantiacus) reports the species solely from broad-leaved trees. Kotlaba (in litt.) reports a collection from Fagus sylvatica.

$P$. fulgens is a weak decayer, and the rot type caused by Fomitopsis pinicola dominates the substrate throughout the growth of this successor. As $P$. fulgens is a saprophyte, it does not seem to cause economic losses in any part of its distribution.

The fruit bodies of $P$. fulgens often appear many years in succession on the same tree trunks. In suitable weather conditions they rapidly reach their final size. They are soon eaten by insects, and disintegrate shortly after becoming mature, so that aged or overwintered fruit bodies are seldom collected.

In the Fennoscandian material the fresh and fertile fruit bodies were collected from the end of July to the end of September. The occurrence has distinct maximum in the second half of August and the first half of September. The collections made in October were mostly overaged, and the dead fruit bodies in poor condition had been collected in November, December, May and June.

\section{Cultural characters}

The cultures of $P$. fulgens have been studied and described by Nobles (1948, 1965), David (1969) and Stalpers (1978), and will therefore be discussed only briefly here. These results are based on the following strains, obtained from fruit bodies or adjacent decayed wood:

Finland:

Varsinais-Suomi, Vihti, Picea abies, 1979 Kotiranta 1506 Uusimaa, Sipoo, P. abies, 1971 Niemelä 424, 453

Uusimaa, Vantaa, P. abies, 1978 Laine \& Korhonen 781003.1 .5 (HFR)

Etelä-Häme, Lammi, P. abies, 1972 Niemelä 444

$P$. fulgens grows rather slowly on malt agar. The radial growth at $24^{\circ} \mathrm{C}$ is $10-14(-18) \mathrm{mm}$ in one week, but the rate of growth varies fairly widely between the strains (one week's growth up to $25 \mathrm{~mm}$ in the strain Niemelä 453). In two weeks the radial growth is $28-36(-50) \mathrm{mm}$, and the Petri dishes with side inoculations are covered by mycelium in $3-4$ weeks. At $35^{\circ} \mathrm{C}$ growth is very slow or almost absent.

After one week the mycelium is translucent, mostly submerged with very low silky aerial hyphae, colourless and without zonation. The margin is thin, indistinct, entire.

The cultures change little with age. They remain almost translucent, but the thin, appressed aerial mycelium becomes pale apricot in colour, with powdery or mealy patches. The cultures have no distinct odour.

In young cultures the generative hyphae are $3-5$ $\mu \mathrm{m}$ in diam., seldom thin-walled, mostly thick-walled to subsolid, negative in $\mathrm{KOH}$. They have simple septa and are branched, especially at the tips. In the translucent areas of old cultures they are (2.5-) 5-8 $\mu \mathrm{m}$ in diam., thin- to thick-walled and tortuous. In the powdery patches they are $3-6 \mu \mathrm{m}$ in diam., less branched, reddish in $\mathrm{KOH}$, and with abundant crystals, droplets and granulous matter between the hyphae. Basidia and basidioles are developed in these dense areas, especially around the inoculum, producing spores $5-7 \times 2.1-3 \mu \mathrm{m}$. These can germinate immediately on agar, producing mycelium which corresponds completely to that derived from the fruit body context. Basidia also develop in the single-spore cultures, and give rise to normal-sized basidiospores. This shows that the species is homothallic, or 'pseudo-homothallic', if the spores have more than one nucleus each. The occurrence of basidia with less than four sterigmata points to the latter possibility.

\section{Notes on P. fulgens}

The bright colour, fibrillose upper surface and dentate pore mouths are generally sufficient to identify the species in the field. Pycnoporus cinnabarinus resembles it in size and colour, but differs in being corky in consistency, and in the even pellicle of the upper surface, and the regular pores.

The great variation in the microscopical characters may sometimes cause confusion. Constant characters are the monomitic structure, the lack of clamps and the presence of long cystidioles. The hyphal wall thickness varies between two extremes: the walls are thin in young specimens, but become almost solid in old fruit bodies. The staining in $\mathrm{KOH}$ accords with these changes, and in young specimens the hyphae of the hymenial trama often remain almost unstained. The hyphae of the context always stain - from faint pink to deep orange red. This is one of the best 
characters differentiating badly preserved specimens from the other monomitic, clampless species of the genera Inonotus, Inonotopsis and Phaeolus. The red staining of Pycnoporellus fulgens was quite distinct even in the oldest herbarium specimens studied, including the type.

The changes in the spore size are remarkable, though they have not received much attention in the literature. Overholts (1953) noted this variability and considered that it depended upon the age of the sporophores. This is partly true, but one may often find spores of all sizes within the given limits in a single collection. It may be that unripe spores are liberated exceptionally easily in microscopic mounts, thus causing variation in the measurements. Spore prints gathered in nature were not studied. Or then the variation may be real; evidence that this may be so is the fact that besides the typical four-spored basidia, basidia with two (or even one or three) spores are also common.

The thin-walled, projecting cystidioles are met with regularly, although in some specimens they are scarce. They can be seen most easily near the bottoms of the tubes. Of much less regular occurrence are the other sterile elements, the pointed, thick-walled hyphal tips, staining red in $\mathrm{KOH}$, which penetrate through the hymenium. The cystidioles were called the 'pseudosetae' by Kotlaba and Pouzar (1963). Personally I do not favour the use of this term, because it is too suggestive of the Hymenochaetaceae and their setae.

Ryvarden (1978) noted that the encrusted matter deposited on the hyphae takes a red stain in $\mathrm{KOH}$. This is true, but the hyphae themselves also very clearly stain red. All things considered, $\mathrm{KOH}$ is the best medium for studying the microscopical characters of the species. Mounts in Cotton Blue, lactophenol or Melzer's reagent are much messier, and the characters remain unclear in these solutions, especially those of the hymenium.

Acknowledgements. I am indebted to Dr. František Kotlaba for reviewing the literature, to Dr. Erast Parmasto for placing his distribution data of $P$. fulgens in Estonia at my disposal, and to Dr. Mme Alix David for her taxonomical notes. I also thank Dr. Reino Alava, Dr. Lars Fagerström, Dr. Kurt Hjortstam and Dr. Lalli Laine for allowing me to publish details of their recent collections, and the curators of the herbaria for the loans.

I am especially grateful to Mr Heikki Kotiranta, M.Sc., for pleasant companionship during the two collecting trips to Pisavaara. He also carried out the laboratory work for the cultural studies, partly wrote these sections, and made many suggestions for the improvement of the manuscript.

The English of this paper was revised by Mrs Anna A. Damström, M.A. The work was supported by grants from the Academy of Finland, and the Jenny and Antti Wihuri Foundation (Finland).

\section{References}

Ahti, T., Hämet-Ahti, L. \& Jalas, J. 1968: Vegetation zones and their sections in northwestern Europe. - Ann. Bot. Fennici 5: 169-211.

Barbas, P. 1980: A propos de Phaeolus fibrillosus Karsten. - Bull. Trimestriel Soc. Mycol. France 96 (1): 7-8.

Baxter, D. 1938 ('1937'): Some resupinate polypores from the region of the Great Lakes 9. - Pap. Michigan Acad. Sci. Arts Lett. 23: 285-305.

Błoński, F. 1889: Fungi Polonici novi. - Hedwigia 28: $280-282$.

Bondarcev, A. 1953: Trutovye griby evropejskoj časti SSSR i Kavkaza. - 1106 pp. Moskva.

Bourdot, H. \& Galzin, A. 1927: Hyménomycètes de France. - 761 pp. Sceaux.

Bresadola, G. 1897: Hymenomycetes Hungarici Kmetiani. - Atti I.R. Accadem. Sci. Lett. Arti Agiati Rovereto (serie terza) 3: $66-117$.

-’- 1920: Selecta mycologica. - Ann. Mycol. 18: 26-70.

David, A. 1969: Caractères culturaux et cytologiques de quelques espéces rengées par Bourdot et Galzin et d'autres auteurs dans le genre Phaeolus (Polyporacées). - Naturaliste Canad. 96: 211-224.

Domański, S. 1959: Dwa rzadkie gatunki grzybów: Leptoporus lapponicus (Rom.) Pil. i Phaeolus alboluteus (Ell. \& Ev.) Pil. w Puszczy Białowieskiej. Monogr. Bot. 8: 171-181.

Domański, S., Orłoś, H. \& Skirgiello, A. 1973: Fungi: Polyporaceae 2, Mucronoporaceae 2, Ganodermataceae, Bondarzewiaceae, Boletopsidaceae and Fistulinaceae. - 332 pp. Warsaw.

Donk, M. 1971: Notes on European polypores 8. Persoonia 6: 201-218.

-"- 1974: Check list of European polypores. - $469 \mathrm{pp}$. Amsterdam.

Eriksson, J. \& Strid, A. 1969: Studies in the Aphyllophorales (Basidiomycetes) of northern Finland. - Ann. Univ. Turku (A II) 40 (Rep. Kevo Subarctic Sta. 4): $112-158$.

Fries, E. 1852: Nya och sällsynta svamparter. - Öfversigt Kongl. Vetenskaps-Akad. Förhandl. 9(6): 129-131.

Gilbertson, R. \& Budington, A. 1970: New records of Arizona wood-rotting fungi. - J. Arizona Acad. Sci. 6: $91-97$.

Gilbertson, R., Burdsall, H. \& Larsen, M. 1975: Notes on wood-rotting Hymenomycetes in New Mexico. Southwestern Naturalist 19: 347-360.

Gilbertson, R. \& Lombard, F. 1976: Wood-rotting Basidiomycetes: Itasca State Park annotated list. - J. Minnesota Acad. Sci. 42: 25-31.

Gilbertson, R., Martin, K. \& Lindsey, J. 1974: Annotated check list and host index for Arizona wood-rotting fungi. - Univ. Arizona Agr. Exper. Sta. Techn. Bull. 209: $1-48$.

Hintikka, V. 1970: First record of Pycnoporellus alboluteus in NW Europe. - Karstenia 11: 33-34.

Imazeki, R. \& Hongo, T. 1965: Coloured illustrations of fungi of Japan I-II. $-181+235$ pp. Osaka.

Karsten, P. 1859: Sydvestra Finlands polyporeer. - 47 pp. Helsingfors.

- $\because$ 1866: Fungi Fenniae exsiccati IV: 301-400. - Ảbo.

-'- 1889: Fragmenta mycologica 28. - Hedwigia 28: $363-367$.

Kawamura, S. 1955: Icones of Japanese fungi I-II. -85 $+89 \mathrm{pp}$. Tokyo.

Komarova, E. 1964: Opredelitel' trutovyh gribov Belorussii. - 343 pp. Minsk.

Kotlaba, F. \& Lazebniček, J. 1967: IV sjezd evropských 
mykologú, Polsko 1966. - Česká Mykologie 21: $54-59$.

Kotlaba, F. \& Pouzar, Z. 1963: Tr̆i význačné choroše slovenských Karpat. - Ceská Mykologie 17: 174-185.

Lisiewska, M. 1979: Flora macromycetes Swiętokrzyskiego Parku Narodowego. - Acta Mycologica 15: 21-43.

Lloyd, C. 1922: Mycological notes 66. - Mycol. Notes C.G. Lloyd 7(1): 1105-1136.

Lowe, J. 1956: Type studies of the polypores described by Karsten. - Mycologia 48: 99-125.

-" 1966: Polyporaceae of North America. The genus Poria. - State Univ. Coll. For. Syracuse Univ. Techn. Publ, 90: 1-183.

-"- 1975: Polyporaceae of North America. The genus Tyromyces. - Mycotaxon 2: 1-82.

Lyubarskij, L. \& Vasil'yeva, L. 1975: Derevorazrušayuščie griby Dal'nego Vostoka. - $164 \mathrm{pp}$. Novosibirsk.

Mazelaitis, J. 1976: Lietuvos TSR afiloforiečiı eiles grybai. $-380 \mathrm{pp}$. Vilnius.

Murrill, W. 1905: The Polyporaceae of North America 12. A synopsis of the white and bright-colored pileate species. - Bull. Torrey Bot. Club 32: 469-493.

-" 1907: Polyporaceae. - North American Flora 9: 1-72.

Neuman, J. 1914: The Polyporaceae of Wisconsin. Wisconsin Geol. Nat. Hist. Survey Bull. 33: 1-156.

Niemelä, T. 1980: Lahottajasienten yhteispeliä. Sienilehti 32: 3-5.

Nobles, M. 1948: Studies in forest pathology 6 . Identification of cultures of wood-rotting fungi. Canad. J. Res. (C) 26: 281-431.

-'-1965: Identification of cultures of wood-inhabiting Hymenomycetes. - Canad. J. Bot. 43: 1097-1139.

Overholts, I. 1953: The Polyporaceae of the United States, Alaska, and Canada. - 456 pp. Ann Arbor.

Parmasto, E. 1963: K mikologičeskoj flore Komi ASSR. Tartu Riikliku Ülikooli Toimetised 136 (Bot.-Alased Töö 6): 103-129.

Parmasto, L. \& Parmasto, I. 1979: The xanthochroic reaction in Aphyllophorales. - Mycotaxon 8: $201-232$.

Pegler, D. 1973: The polypores. - Bull. British Mycol. Soc. 7 (Suppl.): 1-43.

Pilát, A. 1936-1942: Polyporaceae 1-2. In: Kavina, C. \& Pilát, A. (eds.), Atlas des champignons de l'Europe 3. - 624 pp., 374 pls. Praha.

Reid, D. 1965: May fungi in Portugal. - Revista Biol. (Lisboa) 5: 135-158.

Ryvarden, L. 1978: The Polyporaceae of North Europe 2. Inonotus to Tyromyces. - Pp. 219-507. Oslo.

Shope, P. 1931: The Polyporaceae of Colorado. - Ann. Missouri Bot. Garden 18: 287-456.

Stalpers, J. 1978: Identification of wood-inhabiting Aphyllophorales in pure culture. - Stud. Mycol. (Baarn) 16: 1-248.

Stepanova-Kartavenko, N. 1967: Afilloforovye griby Urala. -295 pp. Sverdlovsk.

Subin, V. \& Krutov, V. 1979: Griby Karelii i Murmanskoj oblasti. - 104 pp. Leningrad.

Švarcman, S. 1964: Geterobazidial'nye i avtobazidial'nye griby. In: Flora sporovyh rastenij Kazahstana 4. - 715 pp. Alma-Ata.

Teivainen, L. 1949: Pisavaaran luonnonpuiston metsäkasvillisuudesta ja kasvistosta_(Ref.: Zur Waldvegetation und Flora des Naturschutzgebietes Pisavaara). - Silva Fennica 65: 1-34.

-"-1952: Pohjois-Suomen tuoreiden kangasmetsien kasvillisuudesta (Ref.:Über die Vegetation der frischen Heidewälder in Nordfinnland). - Ann. Bot. Soc. Zool.Bot. Fennicae Vanamo 25(2): 1-168.

Tortić, M. \& Jelić, M. 1969: Some interesting macromycetes and their distribution in Jugoslavia. Acta Bot. Croatica 28: 379-386.

."- 1974: New European records of Tyromyces kmetii and Pycnoporellus alboluteus (Polyporaceae) and the identity of Irpex woronowii Bres. - Česká Mykologie 28: $26-34$.

Accepted for publication on September 20, 1980 